\title{
DISERTACIONES
}

Estudios sobre imágenes en el nuevo ecosistema mediático

ISSN: $1856-9536$

Doi: https://doi.org/10.12804/revistas.urosario.edu.co/disertaciones/a.8157

Volumen 13, Número 2 / Julio-diciembre 2020

Versión PDF para imprimir desde

http://revistas.urosario.edu.co/index.php/disertaciones

Para citar este artigo: Alves da Silva, M., \& Bueno, T. C. (2020). Profissão: como o telejornalista enxerga o impacto da participação da audiência por meio do vídeoamador na sua prática. Anuario Electrónico de Estudios en Comunicación Social "Disertaciones”, 13(2), 1-20. https://doi.org/10.12804/revistas.urosario. edu.co/disertaciones/a.8157

\section{PROFISSÃO: COMO O TELEJORNALISTA ENXERGA O IMPACTO DA PARTICIPAÇÃO DA AUDIÊNCIA POR MEIO DO VÍDEOAMADOR NA SUA PRÁTICA ${ }^{1}$}

Profesión: Cómo el periodista de televisión ve el impacto de la participación de la audiencia por medio de videos aficionados

Profession: How Television Journalists See the Impact of Audience Participation through Amateur Video on Their Practice

Marcelli Alves da Silva, Universidade Federal do Maranhão (Brasil)

alves.marcelli@yahoo.com.br

Thaisa Cristina Bueno, Universidade Federal do Maranhão (Brasil)

tbueno@gmail.com

Recebido: 05 de agosto de 2019

Aprovado: 27 de março de 2019

Data da pré-publicação: 7 de julho de 2020

1 Este trabajo se llevó a cabo con el apoyo de la Coordinación para la Mejora del Personal de Educación Superior -Brasil (CAPES) - Código de Financiamiento 001. 


\section{RESUMO}

Este artigo quer entender, a partir da perspectiva do telejornalista, qual o papel do público que envia vídeos para a redação na rotina do veículo. $\mathrm{O}$ objeto de análise foi o Jornal Nacional, da Rede Globo de Televisão. Metodologicamente foi mapeada toda a produção do telejornal no ano de 2016 e encontrados 5901 materiais informativos. Destes, 239 continham vídeos amadores. As regiões mais participativas do país, por meio do envio de vídeo amador, foram: Centro-Oeste, Sudeste, Nordeste, Norte e Sul. Esse diagnóstico levou a escolha dos entrevistados. Ao todo foram entrevistados oito telejornalistas. Concluiu-se que embora o profissional entenda a importância da participação do público - ele reconhece a produção amadora como uma fonte diferenciada - esta não chega a ser vista como parte da produção, ou seja, o amador não chega a ser entendido como um colaborador da rotina propriamente dito. Nas falas dos entrevistados é possível ver que o telejornalista utiliza da ideologia profissional para reafirmar a importância da profissão no contexto de jornalismo participativo.

Palavras-chave: telejornalista, vídeoamador, jornal nacional, participação da audiência.

\section{RESUMEN}

Este artículo busca entender, a partir de la perspectiva del periodista de televisión, cuál es el papel del público que envía videos a la redacción, para la emisión del noticiero. El objeto de análisis fue el Noticiero Nacional, de Rede Globo de Televisão. Metodológicamente, fue mapeada toda la producción del noticiero en el año 2016 y se encontraron 5901 materiales informativos. De estos, 239 contenían videos aficionados. Las regiones más participativas del país, mediante el envío de videos aficionados fueron: Centro oeste, Sureste, Noreste, Norte y Sur. Ese diagnóstico llevó a la elección de los entrevistados. En total, fueron entrevistados ocho periodistas de televisión. Se concluyó que, a pesar de que el profesional entiende la importancia de la participación del público, pues reconoce la producción aficionada como una fuente diferenciada, esta no llega a ser vista como parte de la producción, o sea, el aficionado no llega a ser entendido como un colaborador de la emisión propiamente dicho. En las conversaciones con los entrevistados es posible ver que el periodista de televisión utiliza la ideología profesional para reafirmar la importancia de la profesión en el contexto del periodismo participativo.

Palabras clave: periodista de televisión, video aficionado, noticiero nacional, participación de la audiencia.

\section{ABSTRACT}

This article wants to understand, from the perspective of the television journalist, what the role of the public that sends videos to the newsroom is in the routine of the vehicle. The object of analysis was the Jornal Nacional, from Rede Globo de Televisão. Methodologically, all the news production in 2016, found in 5901 informative materials were mapped. Of these, 239 contained amateur videos. The most participative regions of the country through amateur video sending were Midwest, Southeast, Northeast, North, and South. This diagnosis led to the choice 


\section{DISERTACIONES}

\section{ESTUDIOS}

Estudios sobre imágenes en el nuevo ecosistema mediático

ISSN: $1856-9536$

Doi: https://doi.org/10.12804/revistas.urosario.edu.co/disertaciones/a.8157

Volumen 13, Número 2 / Julio-diciembre 2020

Versión PDF para imprimir desde

http://revistas.urosario.edu.co/index.php/disertaciones

of respondents. In all, eight news reporters were interviewed. The conclusion was that although professionals understand the importance of public participation -he/she recognizes amateur production as a different sourceit is not seen as part of the production, that is, amateurs are not understood as a routine collaborator. In the interviewees' statements, it is possible to see that the television journalist uses professional ideology to reaffirm the importance of the profession in the context of participatory journalism.

Keywords: Telejournalist, video amateur, jornal nacional, audience participation.

É bem verdade que, de um modo mais restrito e controlado pelos veículos, o público continuamente ajudou na construção do conteúdo que recebia, seja por meio de telefonemas, cartas ou visitas às redações. Ainda assim, como descrevem Schmidt e Zanotti (2009), cabia ao jornalista o papel central, sendo eles "os atores principais nas etapas de apuração e redação do que seria divulgado" (p. 3). Com a internet, a prática do jornalismo passa por diferentes transformações e hoje, como defende Bueno (2012), "a relação de proximidade, concretizada na participação, não é um desejo exclusivo do público, é também uma estratégia editorial dos veículos para garantir identificação e fidelização" (p. 3).

À medida que se consolidavam as diversas tecnologias - dispositivos móveis, algoritmos de rastreabilidade da audiência, redes sociais, entre outras - no dia a dia das redações, o público acabou por se tornar mais atuante e sua participação, por fim, se configurou em uma categoria do jornalismo, atendendo a nomes como "jornalismo cidadão e/ou participativo" (Gillmor, 2004, p. 27), "jornalismo open source” (Brambilla, 2005, p. 32), "jornalismo colaborativo" e, ainda com origens no inglês, jornalismo de grassroots, só para citar algumas. Nesse emaranhado de distinções, cujas particularidades não estão entre os objetivos deste artigo, encontra-se uma prática de produção que faz uso de material em vídeo enviada pelo público, conhecida popularmente por "uso do vídeoamador". É esta modalidade o foco de investigação desta pesquisa, que busca entender como os jornalistas veem a relação com seu telespectador por meio desses produtos audiovisuais produzidos pela audiência.

A participação da audiência por meio do fornecimento de imagens rompe com padrões. Atualmente, dependendo do tipo de imagem (o que ela retrata), a própria imagem amadora enviada pela audiência pode ser a notícia do dia. $O$ estudo do norte-americano Pavlik (2007), inclusive, defende que nesse cenário, os jornalistas precisarão aumentar os seus padrões para que as pessoas possam se interessar pelo que eles produzem. No entanto, ressalta que, frente a um grande volume de informações que atinge a sociedade dia após dia, é preciso um intermediador, "alguém que colabora para a construção do sentido das coisas" (Pavlik, 2007, p. 149).

Tanto é assim que o fluxo de informações oriundas do público que chegam às emissoras de televisão têm sido cada vez maior, sendo incentivada pelos próprios telejornalistas. É comum os telejornais criarem quadros, chamadas e outros blocos similares, incentivando os membros da audiência a enviar às redações flagrantes de situações 


\section{DISERTACIONES}

ESTUDIOS

Estudios sobre imágenes en el nuevo ecosistema mediático

ISSN: $1856-9536$

Doi: https://doi.org/10.12804/revistas.urosario.edu.co/disertaciones/a.8157

Volumen 13, Número 2 / Julio-diciembre 2020

Versión PDF para imprimir desde

http://revistas.urosario.edu.co/index.php/disertaciones

gravadas em seus smartphones, que julgam relevantes para divulgação. Habermas (2006) utiliza a terminologia "descentralização dos acessos" (p. 72) na tentativa de explicar o caráter democratizador da web que influenciou também os outros meios. No entanto, a alegação do autor é de que essa democracia eletrônica está mais voltada para a intenção de aumento da audiência do que de fato para "dar voz" a todos.

A utilização constante de vídeos amadores nos telejornais marca, para Gomes (2005), uma ruptura na forma de participação da audiência. De acordo com ele, antes dessas utilizações, o cidadão comum contava apenas com três maneiras para participar do noticiário: quando era afetado pelas notícias; quando ele próprio se transformava em notícia; ou então quando a cobertura noticiosa contava com o "fala povo".

Neste contexto, propomos analisar como o jornalista vê essas práticas e como elas podem ou não afetar o modo como se enxergam. $\mathrm{O}$ objeto de estudo selecionado é o Jornal Nacional, exibido na Rede Globo de Televisão. Essa escolha se justifica em função de ser este telejornal considerado o de maior audiência da emissora por diversos anos consecutivos e por este veículo, efetivamente, fazer uso do material identificado como "vídeoamador" na sua produção cotidiana. ${ }^{2}$ Ao todo, foram entrevistados oito jornalistas de cinco afiliadas da Rede Globo que em 2016 receberam material amador e o usaram na produção do Jornal Nacional enviando esses vídeos para a emissora nacional. Os critérios para a seleção da amostra foram: a escolha de profissionais que pertenciam às regiões mais participativas de acordo com o levantamento que é parte da pesquisa que compõe esse artigo; que estivessem inseridos no contexto do telejornalismo (exercessem a função de repórter, produtor, editor de texto ou apresentador) e que trabalhassem nas afiliadas da Rede Globo de Televisão.

A pesquisa tem como base teórica a sociologia das profissões, já que discute como essa participação interfere no fazer e no modo como esses jornalistas se veem nesse mercado. Para situar melhor essa corrente teórica, é importante destacar que a definição de profissão no contexto sociológico surge na Inglaterra, no ano de 1933, com o pensamento de Carr-Saunders e Wilson. Eles trabalharam a ideia de que as profissões e as carreiras a elas associadas são partes da união de atividades humanas ligadas a um grande subsistema, com funções e papéis definidos e interdependentes. "A base da classificação era a existência de um corpo organizado que dominasse um conhecimento baseado num sistema de ensino e treinamento, com seleção prévia através de exame, e possuísse códigos de ética e de conduta" (Bonelli, 1993, p. 32).

Atualmente, três correntes de estudos relacionados à sociologia das profissões ganham destaque: a funcionalista, que tem como base Durkheim e Parsons; a interacionista, voltada à Escola de Chicago; e a Neoweberiana, baseada em Eliot Freidson e Magali Sarfatti Larson. Neste artigo optamos pelo estudo interacionista por acreditarmos que a referida linha de pensamento atende de forma mais direta os anseios desta pesquisa, já que esta orientação teórica entende a profissão a partir da relação entre sujeitos e o meio em que está inserido.

2 Estudo de Alves (2014) mostrou, por meio de um mapeamento dos vídeos amadores que compuseram o corpo da notícia televisiva e foram exibidos no Jornal Nacional, na Rede Globo de Televisão, que durante o ano de 2014, 96 materiais dessa natureza fizeram parte do corpo de notícias naquele veículo. 


\section{DISERTACIONES}

ESTUDIOS

Estudios sobre imágenes en el nuevo ecosistema mediático

ISSN: $1856-9536$

Doi: https://doi.org/10.12804/revistas.urosario.edu.co/disertaciones/a.8157

Volumen 13, Número 2 / Julio-diciembre 2020

Versión PDF para imprimir desde

http://revistas.urosario.edu.co/index.php/disertaciones

\section{Conceituando brevemente a relação com a audiência}

O vídeoamador é uma forma de se relacionar com a audiência que integrou a rotina no ciberjornalismo televisivo. Neste sentido, se faz importante, ainda que brevemente, pontuar uma distinção conceitual entre participação, interação e colaboração. Ao tentar traçar um panorama de particularidades entre interatividade, colaboração e participação, Matheus (2013) faz a seguinte distinção: associa interatividade à "dimensão da possibilidade técnica de interferência no conteúdo das mídias" (p. 46), ou seja, uma probabilidade ligada diretamente ao canal; colaboração a uma interferência direta do público na produção noticiosa; e participação, por sua vez, seria "a dimensão política da colaboração", ou seja, um nível ativo e simbólico do usuário. Das três percepções apresentadas pela autora, a participação seria a que efetivamente traria uma mudança significativa no âmbito social. Opinião bem parecida com a de Jenkins (2009) que também propõe uma separação dos termos interatividade e o duo interação/ participação. Para ele, a primeira remete ao "modo como as tecnologias foram criadas para responder ao feedback do consumidor" (p. 189) e, portanto, diferentes graus de interatividade dependeriam diretamente dos distintos suportes; já interação/participação teriam uma qualidade mais social uma vez que são "moldadas por protocolos culturais". Para Jenkins (2009) cada vez mais na web a interação assumida pelo público com relação aos produtos midiáticos que consome tem acontecido de forma não prevista pela interatividade. "Afinal, permitir que interajam dentro de um controle é uma coisa, deixar que participem da produção e distribuição de bens com regras próprias é outra totalmente diferente" (Jenkins, 2009, p. 189). Os vídeos amadores ainda não materializam essa ideia, já que dependem muito da decisão editorial dos veículos. Ou seja, representam uma interatividade do ponto de vista tecnológico, mas ainda criam ruídos no âmbito da participação/interação.

Vittadini (1995) também propõe essa distinção entre interatividade e interação, sendo que na sua classificação a interatividade é um modelo que prevê, de alguma forma, o contato interpessoal; já a segunda seria, substancialmente, uma relação mediada. Conforme escreve, a interação é "um tipo de comunicação possível graças às potencialidades específicas de configurações tecnológicas particulares" (Vittadini, 1995, p. 154, tradução livre). ${ }^{3}$

Vale retomar aqui o diálogo com Primo (2000), que propõe distinguir dois modelos de comunicação interativa: um modelo interativo mútuo e o outro reativo, sendo que o primeiro prevê a autonomia do receptor e o segundo é marcado pelas limitadas possibilidades de escolha deste. E, ao pensarmos em níveis distintos e modelos peculiares de interação do receptor com a mídia e com outros receptores, cabe dialogar, também, com pressupostos de Thompson (2010). De tudo o que escreveu talvez o mais interessante para a discussão levantada neste estudo seja a noção de "interação quase mediada", conceito este apresentado em contraposição aos outros dois tipos de interação possíveis do seu ponto de vista: a interação face a face, marcada pela presença física dos integrantes em espaço e tempo e pelo diálogo; e a interação mediada, balizada pela necessidade patente de um meio que a mantenha, como um papel ou a fibra óptica. $O$ terceiro formato de interação, a "quase mediada", é aquela cuja intercessão é feita pela mídia de massa, sem que haja como intervir diretamente no conteúdo no momento em que está passando.

3 "Un tipo de comunicación posible gracias a las potencialidades específicas de unas particulares configuraciones tecnológicas”. 


\title{
DISERTACIONES
}

\section{ESTUDIOS}

Estudios sobre imágenes en el nuevo ecosistema mediático

ISSN: $1856-9536$

Doi: https://doi.org/10.12804/revistas.urosario.edu.co/disertaciones/a.8157

Volumen 13, Número 2 / Julio-diciembre 2020

Versión PDF para imprimir desde

http://revistas.urosario.edu.co/index.php/disertaciones

Ao tratar do assunto, Santaella (2004) ressalta que o surgimento da comunicação mediada pelo computador, particularmente pelas "configurações informacionais" que acontecem, acarreta profundas mudanças no formato clássico de interatividade e no desenho habitual de comunicação. A autora pontua, por exemplo, transformação diretamente no juízo do que é hoje a figura do receptor, na natureza da mensagem e no papel que ocupa o emissor.

Essa noção de que a comunicação mediada borrou verdadeiramente os papéis tradicionais dos envolvidos na relação parece não causar mais estranhamento. "A participação é vista como uma parte normal da operação da mídia, e os debates atuais giram em torno das condições dessa participação” (Jenkins, 2009, p. 329).

\section{O amador e a visão interacionista}

De acordo com Flichy (2010):

\begin{abstract}
Um amador é, por definição, um não-profissional, uma pessoa que desenvolve gradualmente uma expertise que lhe dá prazer. $\mathrm{O}$ que distingue o amador do profissional, é menos a sua habilidade e mais sua baixa qualificação, uma outra forma de envolvimento em práticas sociais (p. 12).
\end{abstract}

Keen (2009) diz que o sentido tradicional da palavra amador é muito claro: "um amador é quem cultiva um hobby, podendo ser culto ou não, alguém que não ganha a vida com seu campo de interesse, um leigo a quem faltam credenciais, um diletante" (p. 38). Ruellan (2011) discute o termo amador no contexto do jornalismo e afirma que "essa distinção faz parte de uma batalha na história da profissão para obter um status profissional" (p. 32). Sobre essa discussão, Fidalgo (2005) pondera:

\footnotetext{
Insistir em adjetivar o jornalista de "profissional" pressupõe que pode, de fato ou de direito, haver jornalistas

"não profissionais" - com isso podendo significar "amadores" "diletantes", "aprendizes", "principiantes", "incompetentes"... -, o que, por si só, é revelador de uma dificuldade de delimitação nada comum nas chamadas 'profissões estabelecidas', interiorizadas pela opinião pública com base no modelo do profissional liberal (médico, advogado, engenheiro) (p. 2).
}

Para Fidalgo (2005) a questão geográfica também influencia na maneira como a sociedade entende tais fatores. "Nos países do universo anglo-saxônico, já de há muito se faz a distinção entre professions e occupations, sendo que as primeiras têm até, no caso dos EUA, definidas em texto legal as suas obrigatórias atribuições” (p. 2). Ele argumenta, ainda, que atributo de profissão está reservado às atividades que preenchem os requisitos associados às profissões liberais.

De acordo com ele, não é essa realidade encontrada nos países europeus. Nestes países, o termo profissão é utilizado de uma forma mais genérica, e, portanto, mais indefinida. O autor recorre a Dubar e Tripier (1998, apud Fidalgo, 2005) para tentar explicar três universos de significação associados ao uso do termo profissão em francês, mas cuja correspondência com o termo em português é total: 


\section{DISERTACIONES}

ESTUDIOS

Estudios sobre imágenes en el nuevo ecosistema mediático

ISSN: $1856-9536$

Doi: https://doi.org/10.12804/revistas.urosario.edu.co/disertaciones/a.8157

Volumen 13, Número 2 / Julio-diciembre 2020

Versión PDF para imprimir desde

http://revistas.urosario.edu.co/index.php/disertaciones

(1) Qualquer coisa que se enuncia publicamente e que está ligado a crenças político-religiosas (é a chamada 'profissão de fé', o 'professar certas crenças ou valores'), como (2) "o trabalho que se faz, na medida em que nos permite viver graças ao rendimento que dele retiramos” (esta acepção é próxima da 'ocupação' e costuma incluir-se nos elementos básicos de identificação de uma pessoa, a par de nome, estado civil, naturalidade, residência...), ou finalmente como (3) "conjunto de pessoas que exercem o mesmo ofício" (e o sentido, aqui, é próximo do de 'corporação' ou de 'grupo profissional' (Dubar \& Tripier, 1998, p. 78 apud Fidalgo, 2005, p. 2).

Além desses três universos de significação, os autores citam ainda um quarto, mais recente, de profissão como função, ou seja, uma posição profissional. No entanto, Fidalgo (2005) questiona as definições. Segundo ele, é no paradigma funcionalista que se inscrevem as mais frequentes classificações sobre atividades de trabalho. Nesta perspectiva, o entendimento de profissão deve privilegiar o processo por meio do qual o mais importante não é a definição de uma profissão, mas sim, a identificação das circunstâncias, segundo as quais, as ocupações se transformam em profissão. A perspectiva do Interacionismo Simbólico destaca a diversidade e o conflito de interesse voltados às profissões, além de explorar as mudanças que ocorrem decorrentes desses processos antagônicos.

Na década de 70, Freidson e Larson (1997) tentaram uma síntese das teses marxista e weberiana relativa à análise das profissões. Para Weber (2004) a noção de profissão é como uma vocação, ele a define como uma especialização e coordenação de serviços prestados por uma determinada pessoa que são fundamentais para sua subsistência, de forma duradoura. Ou seja, no contexto dos vídeos oriundos da audiência, muitos são considerados amadores por conta de que o produtor desse tipo de conteúdo não tem essa prática como ocupação e nem mesmo profissão. Ou seja, não é uma mão de obra profissionalizada.

\section{O diploma e o status profissional}

Larson (1977), cujos estudos estão centrados na visão do profissionalismo como uma ideologia, constatou em suas pesquisas que a sociedade geralmente atribui um status maior a determinados integrantes de um reduto profissional e que a formação acadêmica ocupa um papel importante nesta seleção do que é mais ou menos respeitável.

No entanto, percebe-se que abordagens centradas no Interacionismo Simbólico também abarcam questões relacionadas ao diploma. Hughes (1994) ressalta que a divisão do trabalho é fundamental para a interação social. Na opinião do autor, essa divisão evidencia que as diferentes tarefas fazem parte de um todo e a essência está no processo de interação social, ou seja, na troca entre as pessoas durante o seu papel ocupacional. Para o autor, o diploma é definido como licença e representa a permissão legal para que uma determinada pessoa possa desempenhar certas funções. De acordo com ele, o diploma exerce a função de separar integrantes de profissões específicas, enquanto o mandato (obrigação legal de assegurar uma função específica, através do qual é confiada ao trabalhador uma missão) é a garantia para manter essa cisão. Porém, ambos são os responsáveis pelas principais formas como os trabalhos são divididos e como essas funções são segregadas entre os membros da sociedade. 


\title{
DISERTACIONES
}

\section{ESTUDIOS}

Estudios sobre imágenes en el nuevo ecosistema mediático

ISSN: $1856-9536$

Doi: https://doi.org/10.12804/revistas.urosario.edu.co/disertaciones/a.8157

Volumen 13, Número 2 / Julio-diciembre 2020

Versión PDF para imprimir desde

http://revistas.urosario.edu.co/index.php/disertaciones

$\mathrm{Na}$ abordagem interacionista dos grupos profissionais, há dois conceitos-chave: os de licença (que consiste na autorização legal, jurídica, para exercer uma determinada atividade, com isso impedindo outros potenciais candidatos de o fazerem) e de mandato (a correlativa obrigação de prestar esse serviço à sociedade, num espírito desinteressado, como que 'de missão', e sujeito à regras de conduta rigorosas (Fidalgo, 2005, p. 5).

A despeito do jornalismo é importante salientar que a obrigatoriedade do diploma para o exercício da profissão do jornalista foi extinta no Brasil, pelo Supremo Tribunal Federal (STF) em 2009. Fidalgo (2005) destaca o papel do mecanismo econômico e do controle dos mercados na sociedade moderna. Hughes (1958) encara a profissionalização como aquilo que ele chama de "história natural" que para ele nada mais é do que um processo de afirmação de ocupações por oposição ou afastamento dos amadores em desenvolvimento das atividades.

\begin{abstract}
A emergência e desenvolvimento de atividades (como a saúde, a educação, nas quais muitas tarefas eram desenvolvidas em regime de amadorismo) que requerem em número crescente os serviços de profissionais; aumento de ocupações que aspiram ao estatuto de profissão-todos estes tipos de mudanças podem produzir novos pedidos sociais e novas ocupações. A história de muitas profissões está intimamente ligada à ocorrência de mudanças no seio de instituições e aos conflitos que se geram entre os diferentes grupos ocupacionais nelas intervenientes (Rodrigues, 2002, p. 17).
\end{abstract}

É percebido, então, que Hughes (1958) considera mais importante do que definir o que é uma profissão, identificar as circunstâncias segundo as quais as ocupações se transformam em profissões. $O$ autor vê a formação profissional como um meio e não como um atributo. A transação econômica na visão dos interacionistas não é primordial. Mas sim, a conexão entre o caminho presumível e o sistema ocupacional que está relacionado a um grupo de instituições que almejam afiançar às profissões o monopólio de certas funções.

Mais pontualmente sobre ser jornalista e como se constrói esse entendimento da profissão, mais que uma formalização, Karam (2004) relaciona a história da profissão com a construção da identidade do profissional que atua na mídia. Segundo ele, essa edificação "[...] está ancorada na luta pela formulação e consolidação de um ethos profissional jornalístico, que se afirmou, ainda que com enormes dificuldades e limites, nos últimos 200 anos" (Karam, 2004, p. 121). Traquina (2005), para quem o jornalismo é, além do domínio de técnicas, um engajamento, entende que sua profissionalização é um processo contínuo. "Os jornalistas têm estado envolvidos num processo de profissionalização que começou em meados do século XIX e continuou ao longo do século XX” (Traquina, 2005, p. 106).

Autores como Moretzsohn (2002), Adghirni (2004), Marshall (2016), Pereira e Adghirni (2011) e Coelho (2015), só para citar alguns, defendem que o jornalismo hoje passa por uma crise profissional das condições de mercado e, também, de identidade, que incluem cobranças por produtividade e reconfiguração das práticas, particularmente pela constante inserção de novas tecnologias e que isso incide no modo como ele se coloca. Os autores, cada um em seu estudo, convergem no entendimento que questões importantes para a identidade do profissional, como luta por uma sociedade melhor, estão sendo substituídas por preocupações essenciais de manutenção 


\section{DISERTACIONES}

do emprego. Acerca do papel do jornalismo, Santos (2014) escreve que "está sendo debatido nas sociedades contemporâneas devido às mudanças decorridas com a inserção e difusão das novas tecnologias no cotidiano profissional" (p. 3).

A internet, substancialmente, foi uma das inserções que mais impactou nas últimas décadas essa rotina. Acerca dessas mudanças ocorridas a partir da inserção de novas tecnologias no "fazer jornalismo" já podemos pensar numa reconfiguração do trabalho da mídia. Some-se a isso o fato de que, como pondera Coelho (2015), as fronteiras que delimitavam a identidade profissional se diluíram em razão da complexidade do campo da comunicação e, de certa forma, a mediação jornalística é dispensada, pois cada um tem acesso à informação em tempo real, utilizando diversos canais de comunicação.

\section{A discussão entre o amador e o profissional no contexto do telejornalismo}

A discussão voltada à relação entre o amador e o profissional está atrelada ao discurso da profissionalização do jornalismo, assunto que já veio à tona por meio de Ruellan (2009), que caracteriza um hábito de linguagem o fato de um jornalista autodenominar-se jornalista profissional, pois "nunca dizemos professor profissional, advogado profissional ou agricultor profissional” (p. 11). É o mesmo autor o responsável por atribuir ao jornalismo a terminologia "profissionnalisme du flou" como uma metáfora ao jornalismo sem nitidez. 0 autor traz em seu ensaio uma analogia quanto ao jornalismo na França, porém, situação não muito diferente encontra-se no Brasil, particularmente se pensarmos nos registros de "jornalistas precários" que eram emitidos pelos sindicatos, anteriormente ao fim da exigência do diploma, para profissionais que atuavam nos meios de comunicação e não tinham formação superior. Como o mesmo autor diz, o jornalismo não é diferente de outras profissões que constituem um "amálgama frouxo" de segmentos que perseguem objetivos diferentes em períodos diferentes da história.

É fato que a intensificação da participação da audiência, e a consequente entrada dos termos na comunicação, como os explorados por Brambilla (2008), jornalismo open source; Anderson (2006), cauda longa ou jornalismo de código aberto; Traquina (2002), jornalismo cívico; Canavilhas et al. (2011), do jornalismo público; e Gillmor (2004), do jornalismo colaborativo, participativo e/ou cidadão, fez que com a discussão do termo "amador" ficasse em evidência no telejornalismo. Polydoro (2012) utiliza o termo produtores autônomos para tratar da produção dos registros imagéticos que chegam às emissoras. Diferente de Alves (2017), a autora fala especificamente do amador e discute, de acordo com a perspectiva beckeriana, o contexto do amador na produção da notícia televisiva.

Alves (2017), Chaparro (2000), Vizeu (2007; 2008 e 2009), Polydoro (2012), entre outros, assuntam a despeito da temática televisiva. Eles comungam do pensamento de que nas redações de televisão, os postos são bem definidos e todos eles, de alguma forma, uns mais, outros menos, preocupam-se com a imagem da telerreportagem. Essa preocupação decorre do fato de que os atores inseridos nesse contexto, de forma institucionalizada, têm conhecimento prévio da importância desse item para a qualidade de uma telerreportagem. Postura diferente do produtor de conteúdo amador que, de forma geral, não tem conhecimento prévio sobre o assunto. Sendo assim, qual a imagem o telejornalista tem a despeito do produtor de conteúdo amador? Se o produtor de conteúdo consegue espaço no corpo da notícia por qual motivo ele ainda é considerado amador? 


\section{DISERTACIONES}

ESTUDIOS

Estudios sobre imágenes en el nuevo ecosistema mediático

ISSN: 1856-9536

Doi: https://doi.org/10.12804/revistas.urosario.edu.co/disertaciones/a.8157

Volumen 13, Número 2 / Julio-diciembre 2020

Versión PDF para imprimir desde

http://revistas.urosario.edu.co/index.php/disertaciones

\section{Metodologia}

Este estudo tem como base metodológica os princípios do mapeamento aplicados à comunicação —Bueno (2012) - e a realização de entrevistas semiestruturadas, baseadas nos conceitos de Manzini (1990). O gatilho para a pesquisa começa em Alves (2017), que ao levantar, por meio de um inventário nacional, os vídeos amadores que compuseram o corpo da notícia televisiva e foram exibidos no Jornal Nacional, na Rede Globo de Televisão, durante o ano de 2014, constatou que naquele ano 96 materiais noticiosos utilizaram o vídeoamador no corpo da notícia.

No presente artigo foi realizado mapeamento similar, porém, o período de análise foi o ano de 2016 . A proposta era atualizar os dados para entender se a frequência havia sido mantida ou ampliada, dois anos depois, e se confirmada a hipótese de crescimento, entrevistar os jornalistas que atuavam nas emissoras mais participativas para entender como essa interferência na rotina produtiva era recebida por eles.

Os resultados do mapeamento apontam que 239 vídeos amadores participaram como integrantes da notícia televisiva. Um aumento expressivo de 129,44\% se comparado com os resultados de 2014. Essa resposta levou a conclusão que as regiões mais participativas com relação a produção amadora foram, respectivamente: Centro-Oeste, Sudeste, Nordeste, Norte e Sul. ${ }^{4}$ A sondagem exploratória mostrou, também, que as próprias emissoras instigam essa participação, já que os dados mapeados demonstraram que esses vídeos chegam às TVs por meio dos aplicativos das próprias empresas jornalísticas (tabela 1).

Tabela 1. Nome dos aplicativos das emissoras mais participativas

\begin{tabular}{|c|c|c|}
\hline Emissora & Afiliada & Aplicativo \\
\hline TV Mirante & Globo Maranhão & Imirante \\
\hline TV Globo de Goiânia & Globo Goiânia & Jornal na EPTV \\
\hline Globo de São Paulo & Globo Campinas e Região & Tô na Rede \\
\hline TV Roraima & Globo Roraima Hora \\
\hline TV Morena & Globo Mato Grosso do Sul & Bem na Hora \\
\hline TV Centro América & Globo Mato Grosso & Você na TV Liberal \\
\hline TV Liberal & Globo Belém & Tô na Rede \\
\hline TV Amazonas & Globo Amazonas & \\
\hline
\end{tabular}

Fonte: elaboração própria.

4 Para chegar a esses números foi levado em consideração o número de vídeos amadores exibidos no Jornal Nacional no referido ano e correlacionado com o número de habitantes por região do Brasil, de acordo com dados do Instituto Brasileiro de Geografia e Estatística (IBGE). 


\section{DISERTACIONES}

ESTUDIOS

Estudios sobre imágenes en el nuevo ecosistema mediático

ISSN: $1856-9536$

Doi: https://doi.org/10.12804/revistas.urosario.edu.co/disertaciones/a.8157

Volumen 13, Número 2 / Julio-diciembre 2020

Versión PDF para imprimir desde

http://revistas.urosario.edu.co/index.php/disertaciones

As entrevistas semiestruturadas realizadas com oito telejornalistas tiveram como critérios de seleção a escolha de profissionais que pertencessem às regiões mais participativas de acordo com o levantamento de 2016; que estivessem inseridos no contexto do telejornalismo (exercessem a função de repórter, produtor, editor de texto ou apresentador) e que trabalhassem nas afiliadas da Rede Globo de Televisão.

A seleção da emissora se justifica porque além do histórico de líder em audiência, o telejornalismo por ela veiculado, bem como de suas afiliadas, está integralmente inserido no contexto da appificação. Uma tendência que de acordo com Alves (2017) ocorre principalmente pela proliferação dos aplicativos (Apps), programas de softwares disponíveis para usar em smartphones e tablets inteiramente dedicados à contribuição do público. "Inicialmente, esses aplicativos eram utilizados de forma específica e única no ciberjornalismo, mas hoje já atingem outros públicos e o seu uso na televisão, principalmente no telejornalismo, passou a ser comum" (Alves, 2017, p. 26).

Os cargos ocupados pelos entrevistados são os de repórteres, produtores, editores de texto e apresentadores. Optou-se pela diversificação das ocupações de forma proposital, uma vez que toda a cadeia produtiva da notícia televisiva é impactada por esses conteúdos. Então, a intenção foi a pluralidade das respostas. As entrevistas foram realizadas pessoalmente durante os anos de 2017 e 2018. Para manter o anonimato dos jornalistas entrevistados, optou-se por classificá-los por letras, sendo assim definidos: jornalista A, B, C, D, E, F, G e H (tabela 2).

Tabela 2. Identificação dos entrevistados por emissora e região

\begin{tabular}{|c|c|c|}
\hline Nome & Região do país & Afiliada \\
\hline A & Maranhão & TV Mirante \\
\hline B & Goiânia & TV Anhanguera \\
\hline C & São Paulo (Campinas e região) & Globo de São Paulo \\
\hline D & Roraima & TV Roraima \\
\hline E & Mato Grosso do Sul & TV Morena \\
\hline F & Mato Grosso & TV Centro América \\
\hline G & Belém & TV Liberal \\
\hline H & Manaus & TV Amazonas \\
\hline
\end{tabular}

Fonte: elaboração própria.

Tendo como objetivo entender como os telejornalistas enxergavam a aproximação com o colaborador que envia os vídeos amadores na sua rotina, o roteiro de entrevistas foi dividido em quatro eixos:

1. Papel do colaborador: esta categoria buscou entender como os telejornalistas enxergavam o papel do produtor de conteúdo amador na sua rotina de trabalho.

2. Frequência: esta categoria tentou entender a que o telejornalista justifica o aumento da frequência de uso do material de colaboradores na sua produção.

3. Trabalho: esta categoria teve como objetivo entender se os jornalistas enxergavam ou não o amador como alguém que estaria desempenhando parte do papel do jornalista. 


\section{DISERTACIONES}

ESTUDIOS

Estudios sobre imágenes en el nuevo ecosistema mediático

ISSN: $1856-9536$

Doi: https://doi.org/10.12804/revistas.urosario.edu.co/disertaciones/a.8157

Volumen 13, Número 2 / Julio-diciembre 2020

Versión PDF para imprimir desde

http://revistas.urosario.edu.co/index.php/disertaciones

\section{O amador na perspectiva do telelejornalista}

Becker (2006) explora em sua obra o fato que a atuação dos amadores nos espaços profissionais pode provocar constrangimentos éticos, estéticos e técnicos na profissão, desafiando e questionando a autoridade jornalística. Porém, o que se percebe é que a maneira como os telejornalistas tratam as imagens oriundas do público e os enquadramentos dados a elas no telejornalismo mantêm esses colaboradores num papel secundário.

Questionados inicialmente sobre qual lugar ocupa o produtor de conteúdo (colaborador amador) na emissora, as respostas costumam confirmar o posicionamento de Becker (2006). Ficam entre a negação da novidade, cuja justificativa é de que se trata de uma prática comum na rotina da mídia e que vem se destacando por conta do acesso à tecnologia, ou seja, sem grandes impactos; e a crítica aos profissionais, que por comodismo estariam usando um material que poderiam, eles mesmos, conseguir, já que não se trata de um material cujas especificidades poderiam ter um grau de dificuldade grande para se obter.

A: Fala-se muito sobre esse tipo de produção no jornalismo. Mas pergunto: será que se na década de 60, 70 tivesse um fotógrafo lambe-lambe no momento de um flagrante e tirasse uma foto, essa foto não seria usada do mesmo jeito? Acho que sim. O que mudou é que hoje temos a tecnologia que ajuda com a velocidade. $\mathrm{O}$ acesso. Tanto de quem a produz quanto de quem a utiliza. Mas quem faz com que as pessoas entendam o que está acontecendo é o jornalista, ou seja, a narrativa. Se tem a imagem por qual motivo não usar?

B: Acho que isso colabora com aquilo que chamam de jornalismo sentado. Por mais que o jornal utilize as imagens, o jornalista, muitas vezes não corre atrás para ver o desmembramento. A imagem veio até ele e muitas vezes consegue-se apurar por cima, por telefone mesmo. Isso para mim é comodismo, pois, sempre tem algum telespectador filmando, principalmente quando se trata de violência, catástrofe [...].

As respostas dos entrevistados $A$ e $B$ corroboram entre si e convergem em um pensamento que já vem sendo estudado por autores como o francês Neveu (2006) e explorado pelo brasileiro Pereira (2003). Para Neveu (2006), o termo jornalismo sentado, adaptado do francês (jornalismeassis), designa um jornalismo mais orientado para o tratamento de uma informação que não é recolhida pelo próprio jornalista. Dessa forma, opõe-se ao journaliste debout ou jornalista de pé, cuja principal função é recolher informações por meio do contato direto com as fontes. Esse tipo de terminologia vem ganhando fôlego, mesmo que inicialmente tenha sido direcionado ao ciberjornalismo, uma vez que é cada vez mais comum os jornalistas, de forma geral, e aqui se enquadra o telejornalista, passarem muito tempo nas redações. Pensamento que ganha desmembramento com Adghirnni (2004) quando a autora explica que essa terminologia não se aplica ao jornalismo investigativo nem mesmo as grandes reportagens, mas sim, a notícias rápidas. E essas notícias rápidas, a qual a autora se refere, também foi encontrada na resposta de um dos entrevistados, relacionado ao vídeo amador.

Percebe-se ainda um apagamento da função do colaborador, seja na negação de um papel real na rotina, seja entendimento de que seu uso ocorre por "comodismo", que escancara uma crítica a sua adoção. Ou seja, ele tem um papel de pouco destaque.

Seguidamente os jornalistas foram questionados a respeito do aumento de $129,44 \%$ da participação do público no corpo da notícia entre os anos de 2014 e 2016. As respostas remontaram à naturalização do uso da tecnologia e à 


\section{DISERTACIONES}

ESTUDIOS

Estudios sobre imágenes en el nuevo ecosistema mediático

ISSN: $1856-9536$

Doi: https://doi.org/10.12804/revistas.urosario.edu.co/disertaciones/a.8157

Volumen 13, Número 2 / Julio-diciembre 2020

Versión PDF para imprimir desde

http://revistas.urosario.edu.co/index.php/disertaciones

organização da redação, no entanto, retomaram também para a invisibilidade da função do amador, já que seriam "complementações", "ilustrações", mas nunca um conteúdo final ou de grande relevância. As declarações, de um modo geral, enfatizaram o protagonismo do jornalista.

C: Veja bem. É fato que em 2014 o telejornalismo da emissora não estava tão bem organizado quanto a utilização de recursos que pediam para o público participar. E mesmo as que já estavam utilizando aplicativos, os próprios jornalistas ainda estavam se adaptando a essa nova modalidade. Isso já se consolidou. Já se organizou. Mas, uma coisa é fato. As imagens que enviam para a gente é sempre de fatual, algo que vai "enriquecer" um fato ou algo assim. As notícias mais bem trabalhadas, dificilmente dependem desse tipo de imagem. Pode até utilizar, mas apenas para dar um enriquecimento, em se tratando do valor imagético.

Utilizamos mesmo com frequência no dia a dia da redação.

A resposta, além de corroborar o pensamento de Adghirnni (2004), mostra também a resistência do telejornalista quanto ao sentimento de pertencimento do produtor de conteúdo amador na produção da notícia. Ou seja, o entrevistado exime o produtor de conteúdo amador das notícias as quais ele denomina de "mais bem trabalhadas". Abarcando discussão similar, Alves (2017) sugere, por meio de uma análise bekeriana, a terminologia "mundo do telejornalista". Para a autora, o telejornalista não aceita como pertencente ao "seu mundo" o produtor de conteúdo que não esteja institucionalizado. Além disso, Alves (2017) deixa em evidência o pensamento que, um dos motivos do estreitamento dessa relação, é a hiperconcorrência, explorada pelos canadenses Charron e De Bonville (2004).

É fato que a convergência dos meios, anteriormente exploradas por autores como Jenkins (2009), Salaverria e Negredo (2008), Saad (2003), Canavilhas (2012), Pavlik (2007 Ferrareto e Kischinhevsky (2010), propiciou essa nova relação entre o telejornalista e o produtor de conteúdo amador. Relação vista por Keen (2009) de uma forma não muito otimista. Na opinião do autor, o amadorismo domina a produção de informação e leva uma crise ao jornalismo em si. $O$ entrevistado $D$ tem uma opinião relacionada a essa temática.

D: Acho que embora muita gente acredite que essa entrada do público cada vez mais latente na notícia seja o fim do jornalismo, eu acredito que uma coisa não substitui a outra. O repórter amador não substitui o jornalista de forma integral. Mas sabe como eu o vejo: como o estagiário, sabe. Aquele que a gente manda apurar um monte de coisa, faz isso e aquilo, depois passa para o repórter e é esse que finaliza, conclui a narrativa e assina a matéria.

Percebe-se que quando o entrevistado D comenta sobre a narrativa da notícia se refere também ao crédito (assinar) a matéria. Nisto, ele está deixando subentendido algo voltado à Teoria da Comunicação, por meio do conceito de gatekeeper, elaborado por Kurt Lewis, em 1947, por exemplo. De acordo com essa teoria, os jornalistas teriam como parte do seu papel cuidar de uma espécie de gate (portão), e, portanto, cabia a eles decidir o que entrava e o que não entrava no noticiário. Dessa forma, os fatos se transformam em notícia ao passarem pelos portões, mas, caso sejam barrados, teriam como destino final a morte, ou seja, não seriam divulgados. Porém, com a proliferação das redes sociais essa "morte" não é definida apenas pela chancela do jornalista. Sobre isso, Jay Rosen (2006) aponta que as pessoas que anteriormente desenvolviam o seu papel como audiência hoje também podem ocupar o lugar de produtores de conteúdo ou, ao menos, de disseminadores em potencial de informações. Canavilhas (2012) informa que essa mudança provoca uma ruptura em um ecossistema que ainda busca por equilíbrio. 


\section{DISERTACIONES}

\section{ESTUDIOS}

Estudios sobre imágenes en el nuevo ecosistema mediático

ISSN: $1856-9536$

Doi: https://doi.org/10.12804/revistas.urosario.edu.co/disertaciones/a.8157

Volumen 13, Número 2 / Julio-diciembre 2020

Versión PDF para imprimir desde

http://revistas.urosario.edu.co/index.php/disertaciones

Para além da própria mídia utilizar estes canais, os leitores chamaram para si esta atividade, funcionando como uma espécie de novos gatekeepers que comentam e selecionam as notícias mais interessantes para os seus amigos (Facebook) ou seguidores (Twitter) (Canavilhas, 2012, p. 3).

Essa ruptura no trânsito convencional, anteriormente estudado, foi denominado por Bruns (2009) como gatewatching. $\mathrm{O}$ autor explica que as novas tecnologias permitiram ao usuário ignorar as publicações noticiosas para se conectar diretamente com as organizações.

Além disso, estes usuários ativos podem atualmente compartilhar com outros aquilo que observam enquanto estão observando, através de uma ampla gama de plataformas, variando das ferramentas colaborativas para marcar livros, passando pelos blogs pessoais e coletivos até os sites da mídia social, e de lá encontrar e conectar com outros usuários com interesse em temas semelhantes (Bruns, 2009, p. 123).

Porém, o que foi perceptível no pensamento dos jornalistas entrevistados nesta pesquisa é que um vídeo amador pode até ser proliferado nas redes sociais, curtido e compartilhado muitas vezes. Porém, ele é um fato isolado. Uma imagem em si. Ele passa a ser de fato jornalístico e tido como verídico, com credibilidade, a partir da chancela do jornalista. Ou seja, a partir do momento no qual o jornalista permitiu que aquela produção passasse a integrar o corpo da notícia. Por fim, as demais respostas dos entrevistados, sobre a crença de que o produtor de conteúdo amador estaria fazendo parte do trabalho do telejornalista, ratificaram as impressões deixadas nas ponderações anteriores, de que o amador não teria uma função primordial, tendo pouca importância, e por sua vez, o jornalista segue sendo quem define aquilo que é noticiável. Jenkins (2009) já ajuizou sobre essa resistência das mídias tradicionais com a participação cada vez mais presente do colaborador. Embora não tratasse de telejornalismo, ele pondera que a convergência amplia as formas de vender o conteúdo e consolida a fidelização do consumidor, mas cria uma crise de papeis. As declarações dos entrevistados demonstram bem isso.

E - Fazer o trabalho do telejornalista o cinegrafista amador não está fazendo de forma geral. Mas em específico, na reportagem que ele conseguiu participar, ele acabou fazendo, pois muitas vezes a imagem é a própria notícia em si, não é apurado nada a mais, nem entrevistado ninguém. A impressão que eu tenho é que as vezes a TV usa o repórter apenas para ficar subentendido que não poderiam deixar o amador assinar a matéria.

F- Estamos vivendo um momento difícil. Percebo que ao mesmo tempo em que as novas tecnologias estão 'bombando' existe também uma cobrança cada vez maior da concorrência. Muitas vezes o jornalista se acomoda quando sabe que pode contar com a imagem amadora e mesmo assim conseguir, de repente, um "furo". Triste isso.

G - Acho que o jornalista se comporta dessa maneira pois tem a chancela do veículo que faz questão de delimitar: olha esse é amador e esse é profissional, sabe. Tipo, o amador só tem validade pois um repórter validou, ele disse isso, aquilo etc.

H - Vivemos um momento intenso das chamadas fake news. Então, acredito que esse tipo de proliferação de materiais vem para fortalecer o papel do jornalista. Ou seja, enquanto ele está rolando nas redes sociais é uma produção amadora, que pode gerar dúvida, ou mesmo ser taxada de fake. Mas quando ele passa a integrar o corpo da telerreportagem tudo muda. Sabe aquela coisa: deu na TV então é verdade? É isso aí. 


\section{DISERTACIONES}

\section{ESTUDIOS}

Estudios sobre imágenes en el nuevo ecosistema mediático

ISSN: $1856-9536$

Doi: https://doi.org/10.12804/revistas.urosario.edu.co/disertaciones/a.8157

Volumen 13, Número 2 / Julio-diciembre 2020

Versión PDF para imprimir desde

http://revistas.urosario.edu.co/index.php/disertaciones

Essa validação, a chancela do jornalista para que uma produção passe a integrar o telejornal, é visto como o controle por Ruellan (2009):

O interesse do internauta pela cooperação em rede não atende ao interesse da empresa de mídia pela mobilização de recursos e lucros. 0 amador do jornalismo parece permanecer amador no jornalismo. Tudo mudou, e nada, como se a inovação tivesse sido absorvida imediatamente por um controle (p. 60 Tradução livre). ${ }^{5}$

Para o autor, esse controle é um discurso da mídia em geral que é absorvido pelos jornalistas. Questionados por qual motivo mesmo conseguindo compor o corpo da notícia o produtor de conteúdo continua considerado amador, as respostas remontam muito à institucionalização, pertencer a um grupo de mídia, e à apuração, em geral não vinculada ao vídeo enviado:

G - Acho essa discussão uma coisa vaga. Ele é considerado como amador pois naquele momento não estava como um profissional. Por exemplo: se eu estiver na rua e acompanhar um acidente e gravar do meu celular, naquele momento deixo de ser um profissional e faço o trabalho do amador. Com equipamento amador, sem equipe, sem apuração. Apenas gravo. Entende?

D- Eu acho que o repórter não corre o risco de nada, nem do amador tomar o lugar dele e nem acredito que o amador está fazendo o papel do jornalista. O que eu vejo é o seguinte: o jornalista sempre teve que trabalhar com a fonte, sempre. Isso faz parte das normas. A produção amadora é um novo tipo de fonte que emergiu por conta das novas tecnologias.

H - Para mim, as coisas estão muito claras e os papeis muito bem definidos. $\mathrm{O}$ amador, nada mais é do que uma fonte de uma forma diferente. Da mesma forma que alguém dá uma entrevista para validar um material, ou algum órgão envia um documento importante, o amador passa a dar o vídeo amador com um tipo de informação. Ele simplesmente estava em um momento no qual o jornalista não estava. Simples assim.

Nesse sentido, retomamos a seguinte pergunta de Primo (2017): onde acontece o jornalismo? Esse autor contextualiza a sua resposta dizendo que grande parte das práticas do jornalismo ocorre nas redações ou em qualquer lugar no qual a tecnologia está. Ou seja, para relatar um fato o telejornalista precisa da imagem e os fatos ocorrem a todo momento, em todo lugar. Jenkins (2016, apud Alves e Ferreira, 2016) sugere que o papel do jornalista hoje deve ser o de ter o público como seu aliado e assim reforçar o seu papel. "Eu sei que muitos jornalistas pensam que é inapropriado assumir o papel pedagógico, mas para a população adulta, eles podem estar situados de maneira única para fazê-lo. Assim como eles funcionam agora como "verificadores de fatos" (p. 22, Tradução livre). ${ }^{6}$

Ao serem eleitos como Jenkins (2016) sugere fact-checkers, ao pé da letra "verificadores de fatos", os jornalistas reafirmam seu papel no contexto do telejornalismo e deixam, mais uma vez, a produção amadora a mercê do sistema. Assim como as respostas dos entrevistados sugeriram. Nesse sentido, corrobora Alves (2017):

5 L'intérêt de l'internaute pour la coopération réticulaire ne rencontrepasl'intérêt de 'entreprisemédiatiquepourlamobilisation de ressources et profits. L'amateur de journalismeparaîtdemeurer un amateur enjournalisme. Tout a bougé, et rien, commesil'innovationavaitétéabsorbéeimmédiatement par un contrôle.

6 I know many journalists think it is inappropriate to assume a pedagogical role but for the adult population, they may be uniquely situated to do so. Just as they function now as "fact checkers. 


\section{DISERTACIONES}

ESTUDIOS

Estudios sobre imágenes en el nuevo ecosistema mediático

ISSN: $1856-9536$

Doi: https://doi.org/10.12804/revistas.urosario.edu.co/disertaciones/a.8157

Volumen 13, Número 2 / Julio-diciembre 2020

Versión PDF para imprimir desde

http://revistas.urosario.edu.co/index.php/disertaciones

Jornalistas usam as fontes que produzem vídeo amador em busca de notícias impactantes e bem trabalhadas e com isso reforçam o seu reconhecimento entre os pares. Dessa forma, a reputação da equipe e da emissora torna-se cada vez mais reconhecida e a do amador não, uma vez que são raras as vezes em que o seu nome aparece por extenso no crédito das imagens, na verdade, quase sempre, aparece apenas a informação de que são imagens de um cinegrafista amador ou imagens feitas por celular. No entanto, essa reputação, mesmo que seja apenas um reconhecimento entre as pessoas que trabalham formalmente nas redações de um telejornal (p. 260).

Pensamento similiar encontramos em Carvalho (2003). 0 autor afirma que a relevância dada pelos profissionais à sua utilidade social é importante para que o público se convença de que os serviços quando não realizados por profissionais oferecem riscos e, por isso, devem ser executados por um grupo especializado ao qual atribuem prestígio e autoridade. Além disso, percebemos nas entrevistas dos jornalistas para esse trabalho um reforço no discurso voltado a ideologia profissional. Sobre isso recorremos a Traquina e Mesquita (2004), os autores explicam que a ideologia jornalística fornece um ethos que acaba por definir para a sua própria comunidade as ações voltadas tanto a informar o cidadão quanto o de proteger a sociedade. Dessa forma, é evidente que o discurso dos jornalistas atribui a eles mesmos a responsabilidade com a informação, o que, de acordo com o que dizem, não existe com o amador. Além disso, a lógica de tratar a produção amadora como fonte é consenso. Porém, como se trata de um produto novo que chega em grande escala nas redações, percebe-se que os próprios telejornalistas estão aprendendo, na prática, a lidar com ele.

\section{Considerações finais}

Dos achados desta pesquisa, após realizar o mapeamento dos vídeos amadores no Jornal Nacional no ano de 2016, analisar as plataformas de sugestão de envio de imagens às redações e entrevistar oito telejornalistas das regiões mais participativas no país, está o fato de constatar que a appificação nas afiliadas da Rede Globo de Televisão já está consolidada, tanto no dia a dia dos telejornalistas quanto para o público. Uma consolidação que mostra que houve um investimento por parte dos veículos em melhorar essa aproximação com a público, que inclusive é apontada pelos profissionais como a razão para o aumento do recebimento dos vídeos de colaboradores.

Por outro lado, mesmo reconhecendo a importância da participação do público, por meio do envio de vídeos amadores, os telejornalistas não reconhecem os produtores de conteúdo amadores como parte integrante da notícia, como parte do trabalho de jornalista ou mesmo como uma possível ameaça a sua profissão, embora nas suas falas fique muito enfatizado que precisam se reafirmar como profissionais. Como pondera Jenkins (2009) quando diz que os vídeos caseiros nunca incomodaram a indústria de cinema, desde que ficassem em casa. Os jornalistas entrevistados reafirmam o seu lugar (telejornalista) no sentido de chancelar o material para que ele deixe de ser apenas um produto amador e passe a ter espaço no telejornal. Eles ainda trazem em seu discurso questões voltadas à ideologia da profissão e deixam claro que ao mesmo tempo em que a audiência se sente prestigiada pelo estímulo dado pelo telejornalismo, a participação dela também faz parte do interesse mercadológico dessa nova modalidade de relacionamento entre os telejornalistas e os telespectadores. 


\section{DISERTACIONES}

\section{ESTUDIOS}

Palácios e Munhoz (2007) enfatizam que esse tipo de comunicação, que tem como marco a aproximação, é uma forma pela qual as grandes empresas jornalísticas aproveitam o respaldo que possuem junto à comunidade para utilizar a produção feita pelo cidadão comum na tentativa de melhorar a sua cobertura. E esse interesse é visto no discurso dos entrevistados que classificam o produtor de vídeo amador como fonte. Ou seja, um tipo de fonte, ainda nova, que estão aprendendo a lidar, mas que não têm dúvida, esse tipo de participação é uma tendência de um novo modelo do telejornalismo colaborativo.

\section{Referências}

1. Adghirni, Z. L. (2004). Valores-notícia e credibilidade no jornalismo on-line. Anais do II Encontro Nacional de Pesquisadores em Jornalismo (SBPJoR).

2. Alves, M. (2017). O percurso do amador para integrar o "mundo do telejornalista": uma análise dos vídeos colaborativos que participam da notícia televisiva" (Tese de doutorado, Universidade de Brasília, Brasília).

3. Alves, M., \& Ferreira, F. (2016). The citizen at the forefront of news production: a perspective analysis. Revista Rumores - USP, 19(10), 284-287.

4. Anderson, C. (2006). A Cauda Longa: do mercado de massa para o mercado de nicho. Rio de Janeiro: Elsevier.

5. Barbosa, M. L. O. (1993). Reconstruindo as minas e planejando as gerais: os engenheiros e a constituição dos grupos sociais (Tese de doutorado, Universidade de Campinas, Campinas).

6. Brambilla, A. M. (2008) Jornalismo open source: discussão e experimentação do Ohmy- News International. Dissertação de ... Indiana: Wiley Publishing.

7. Becker, B. (2006). A linguagem do telejornal: um estudo da cobertura dos 500 anos do descobrimento do Brasil. Rio de Janeiro: E- papers.

8. Bonelli, M. G. (1999). As Ciências Sociais no Sistema Profissional Brasileiro. BIB, Boletim Informativo e Bibliográfico de Ciências Sociais, 36, p. 55-62.

9. Bueno, T. (2012). Mapeamento como método de Interpretação. In Mapeamento dos programas de treinamento em Comunicação em 2012: relação necessária academia e mercado (p. 98-100). São Paulo: Itaú Cultural.

10. Brambilla, A. M. (2005). Jornalismo open source em busca de credibilidade. In InTERCOM 2005, Anais do XXVIII Congresso Brasileiro Interdisciplinar De Ciências Da Comunicação, Rio de Janeiro.

11. Bruns, A. (2009). Gatewatching: Collaborative online news production. New York: Peter Lang.

12. Canavilhas, J. (2012). Da remediação à convergência: um olhar sobre os media portugueses. Associação Brasileira de Pesquisadores em Jornalismo, SBPJOR. Recuperado de http://bjr.sbpjor.org.br/bjr/article/ viewFile/369/362.

13. Canavilhas, J., Correia, J. C., Carvalheiro, J. R., Morais, R., \& Sousa, J. C. (2011). Jornalismo Público e Educação para os media: sugestões baseadas num projeto de pesquisa sobre Imprensa Regional Portuguesa. Brazilian Journalism Research, (7), p. 58-74. 


\section{DISERTACIONES}

ESTUDIOS

Estudios sobre imágenes en el nuevo ecosistema mediático

ISSN: $1856-9536$

Doi: https://doi.org/10.12804/revistas.urosario.edu.co/disertaciones/a.8157

Volumen 13, Número 2 / Julio-diciembre 2020

Versión PDF para imprimir desde

http://revistas.urosario.edu.co/index.php/disertaciones

14. Chaparro, M. C. (2000). Sotaques d'aquém e d'além mar: percursos e gêneros do jornalismo português e brasileiro. Santarém: Jortejo.

15. Charron, J., \& De Bonville, J. (2004). Typologie historique des pratiques journalistiques. In B. Colette, J. Charron \& J. De Bonville (Orgs.), Nature et transformation du journalisme. Théories et recherches empiriques. Québec: LesPresses de L'Université Laval.

16. Coelho, D. (2015). Jornalismo, sociedade e crítica: potencialidades e transformações (Dissertação de mestrado, Universidade do Vale do Rio dos Sinos, São Leopoldo).

17. Dubar, C., \& Tripier, P. (1998). Sociologie des professions. Paris: Armand Colin.

18. Ferrareto, L. A., \& Kichinhevsky, M. (2010). Rádio e convergência: uma abordagem pela economia política da comunicação. XIX Encontro da Compós, Rio de Janeiro.

19. Freidson E., \& Larson, M. (1997). The Rise of Professionalism. A sociological analysis. London: University of California Press.

20. Fidalgo, J. (2005). Jornalistas: um perfil socioprofissional em mudança. Comunicação e Sociedade, Aveiro, 5(1), 63-74.

21. Flichy, P. (2010). Le sacre de l'amateur: sociologie des passions ordinaires à l'ère numérique. Paris: Éditions du Seuil.

22. Gillmor, D. (2004). We, the media. Lisbon: Editorial Presence.

23. Gomes, I. M. M. (2005). Modo de endereçamento no telejornalismo do horário nobre brasileiro: o Jornal Nacional, da Rede Globo de Televisão. Trabalho apresentado ao NP 07 - Comunicação Audiovisual, V Encontro dos Núcleos de Pesquisa da InTERcom.

24. Habermas, J. (2006). Agir Comunicativo e Razão Destranscendentalizada. Rio de Janeiro: Tempo Brasileiro.

25. Hughes, E. C. (1994). Le regard sociologique. Paris: EHESS.

26. Hughes, E. C. (1958). Man and their work. Toronto, Canadá: The Free Press.

27. Jenkins, H. (2009). Cultura da convergência. 2. ed. São Paulo: Aleph.

28. Karam, F. J. C. (2004). Por que estudar ética jornalística? Comunica Press. Recuperado de https://comunicapress.wordpress.com/2010/04/17/por-que-estudar-etica-jornalistica/

29. Keen, A. (2009). O culto do amador. Como Blogs, Myspace, YouTube e a pirataria digital estão destruindo nossa economia, cultura e valores. Rio de Janeiro: Jorge Zahar.

30. Manzini, E. J. A. (1990). Entrevista na pesquisa social. Didática, São Paulo, 26, 149-158.

31. Matheus, L. C. (2013). O leitor e o cotidiano na história do jornalismo. Revista Eletrônica do Programa de Pós-Graduação em Mídia e Cotidiano, Artigos Seção Livre, 1. Recuperado de http://www.ppgmidiaecotidiano.uff.br/ojs/index.php/Midecot/article/view/15

32. Moretzsohn, S. (2002). Jornalismo em "tempo real": o fetiche da velocidade. Rio de Janeiro: Revan.

33. Neveu, E. E. (2006). Sociologia do Jornalismo. São Paulo: Edições Loyola.

34. Palácios, M., \& Munhoz, P. (2007). Fotografia, blogs e jornalismo na internet: oposições, apropriações e simbioses. In S. Barbosa (Org.), Jornalismo digital de terceira geração (pp. 63-74). Covilhã: LABcom, Universidade da Beira Interior. Recuperado de http://www.labcom.ubi.pt/livroslabcom/fichas/ficha_barbosa_ jornalismo_online.html 


\section{DISERTACIONES}

ESTUDIOS

Estudios sobre imágenes en el nuevo ecosistema mediático

ISSN: $1856-9536$

Doi: https://doi.org/10.12804/revistas.urosario.edu.co/disertaciones/a.8157

Volumen 13, Número 2 / Julio-diciembre 2020

Versión PDF para imprimir desde

http://revistas.urosario.edu.co/index.php/disertaciones

35. Pavlik, J. (2007). Televisão na era digital. Cadernos de televisão: uma metamorfose habilitada pela tecnologia. In Cadernos de Televisão, 1 (pp. 23-54). Rio de Janeiro: Instituto de Estudos em Televisão.

36. Pereira, F. H. (2003). O jornalista online: um novo status profissional? Uma análise sobre a produção da notícia na internet a partir da aplicação do conceito de "jornalista sentado (Dissertação de mestrado). Universidade de Brasília, Brasília.

37. Pereira, F. H., \& Adghirni, Z. L. (2011). O jornalismo em tempo de mudanças estruturais. Intexto, 1(24), 39-57.

38. Polydoro, F. (2012). Esboço de uma ontologia dos vídeos amadores de acontecimentos. Contracampo UFF, 25(1), 134-149.

39. Primo, A. (2017). Interação mediada por computador: comunicação, cibercultura, cognição. Porto Alegre: Sulina.

40. Primo, A. (2000). Interação mútua e reativa: uma proposta de estudo. Revista da Famecos, 12, 81-92. Recuperado de http://www.ufrgs.br/limc/PDFs/int_mutua_reativa.pdf

41. Rosen, J. (2006). Para além da objetividade. Revista de comunicação e linguagem. Lisboa: Relógio D’Água Editores.

42. Rodrigues, M. V. R. (2002). Gestão empresarial: organizações que aprendem. Rio de Janeiro: Qualitymark.

43. Ruellan, D. (2009). Corte e costura do jornalismo. Líbero, 9(18), 31-40.

44. Ruellan, D. (2011). Le Professionnalismedu Flou. Dentité et savoir-faire des journalistes français. Grenoble: PUG.

45. Saad, B. (2003). Estratégias para a mídia digital. São Paulo: Senac.

46. Salaverria, R., \& Negredo, S. (2008). Periodismo integrado: convergencia de medios y reorganización de redacciones. Barcelona: Editorial Sol90.

47. Santaella, L. (2004). Navegar no ciberespaço. O perfil cognitivo do leitor imersivo. São Paulo: Paulus.

48. Santos, R. N. dos. (2014). Jornalismo do século XXI: profissão, identidade, papel social, desafios contemporâneos. In Anais do XIV Congresso de ciências da comunicação da região nordeste, João Pessoa. Recuperado de http://www.portalintercom.org.br/anais/nordeste2014/resumos/R42-0360-1.pdf.

49. Schmidt, S. C., \&Zanotti, C. A. (2009) Jornalismo colaborativo: conceitos e implicações. In Anais do XIV Encontro de Iniciação Científica da PUC-Campinas. Recuperado de https://scholar.google.com/scholar?cluster= $17010528145395470889 \& \mathrm{hl}=$ en\&oi=scholarr.

50. Thompson, J. (2010). A mídia e a modernidade: uma teoria social da mídia. Petrópolis: Vozes.

51. Traquina, N. (2002). Teorias do Jornalismo - tribo jornalística - uma comunidade interpretativa transnacional. Florianópolis: Insular.

52. Traquina, N. (2005) Teorias do Jornalismo: porque as notícias são como são. 2 ed. Florianópolis: Insular.

53. Traquina, N., \& Mesquita, M. (2004). Jornalismo cívico. Lisboa: Livros Horizonte.

54. Vittadini, N. (1995). Comunicar con los nuevos media. In G. Bettetini \& F. Colombo (Eds.), Las nuevas tecnologías de la comunicación (pp. 103-166). Barcelona: Paidós.

55. Vizeu, A. (2007). O telejornalismo como lugar de referência a redução da complexidade nas sociedades contemporâneas. Encontro Nacional de Pesquisadores em Jornalismo, 6. São Paulo: SBPJoR. 


\section{DISERTACIONES}

\section{ESTUDIOS}

56. Vizeu, A. (2008). O telejornalismo como lugar de referência a redução da complexidade nas sociedades contemporâneas. Encontro Nacional de Pesquisadores em Jornalismo, 6, 2008, São Paulo. Programação: a construção do campo do jornalismo no Brasil. São Paulo: SBPJoR.

57. Vizeu, A. (2009). O telejornalismo como lugar de referência e a função pedagógica. Revista FAMECOS, 40, 77-83.

58. Weber, M. (2004). A "objetividade" do conhecimento nas Ciências Sociais. In G. Cohn \& M. Weber (Org.). Sociologia (coleção grandes cientistas sociais) (pp. 175-185). São Paulo: Ática. 